\title{
Near-School Leavers' Perception of Their Vocational and Labour Market Information Needs
}

\author{
Amininiye M. Manuel and Patrick N. Asuquo \\ Educational Foundations, Guidance and Counselling Department, Faculty of Education, \\ University of Calabar, Calabar \\ *E-mail: patasu001@yahoo.com
}

KEYWORDS Skills. Production. Career Choice. Labour Market Information

\begin{abstract}
Survey data collected from one thousand secondary and primary school age cohort on the verge of graduation were analysed to determine the perception of their vocational and labour information needs as well as the extent to which the perception of these needs were coloured by sex differences. The results of this study indicate high levels of vocational and labour market needs amongst both primary and secondary near-school leavers. The results of this study also show no significant differences that exist in the mean response scores of male and female primary and secondary school near-leavers on their perception regarding their vocational and labour market needs. Implications were discussed and recommendations made.
\end{abstract}

\section{INTRODUCTION}

Today's ever-advancing technological world requires specialized skills, which enables school leavers to fit into the production or service lines of industries. In order not to be left behind, school leavers, irrespective of their level of education may seem to perceive their vocational and labour market needs in different ways. Onyejiaku (1987) observed that of all the motivational factors that have strong bearing on the choice of occupations, needs, values and interests seemed to be very significant.

In recent time, Nigeria as one of the developing countries of the world is undergoing rapid educational, socio-cultural and technological developments. This has led to the constant creation of job opportunities as well as more vocational training programmes, which the youths seem to be ignorant about. Because of this problem of ignorance, which the youths have been facing, Obadofin (1997) and Ubulom (1999) revealed that many individuals most especially youths are usually faced with a lot of problems when planning and making career choices. For instance, studies by Olayinka (1993), Gesinde (1986) and Ubulom (1990) have shown that most young people prefer to choose medicine, engineering, law, architecture and pharmacy as the professions they intend to enter into after graduation from schools. People aspire to do certain things because of some basic needs, whether these needs are real or imagined. In essence, one who does not have any need for a particular thing does not worry about such a thing. People engage in some occupations because they feel they lack "something" which if present would give them satisfaction in an expected or anticipated direction (Onyejiaku 1987), and the "something" they feel they lack may be in terms of material wealth such as money or influence, prestige, recognition and so on. This is an indication that some youths may have good aspirations for themselves. However, every youngster who comes to school is encouraged to set high aspirations for him or herself and to work hard to achieve the goals (Olutola 1986). Despite the fact that these youths are encouraged most of them cannot still make realistic career choices.

People's choice of career may tend to influence their perception about their vocational and labour market information needs. In a study carried out by Ubulom (1999), he discovered that students' choice of career is significantly being influenced by the amount of career guidance and counseling received.

Anyaduba (1986) revealed that most of our youths are ill-informed, uninformed and sometimes misinformed about careers that change lives. Hence, for one to go into a particular career, he or she must consider what actually happens in getting into such a career, how preferences change with sex or age and how they are affected by other factors. Obadofin (1997) stressed that vocational guidance and counseling programme should be able to satisfy the vocational needs of the students by helping them to explore the range 
and structure of occupation in the local, state and national levels. This can be facilitated by available data on their information need profile.

It is worrisome that school leavers do not seem to be aware of their vocational and labour market information needs. This probably could make them to be facing the problem of making good career choice. The complexity of the situation has been deepened due to lack of research data. Recently, however, this issue has attracted the attention of scholars, educationists and guidance counsellors. For instance, Eremie and Ubulom (2005) carried out a study to identify the counselling needs in five primary schools in the Port Harcourt metropolis. In their findings, they discovered that there is no existence of counselling services to cater for the vocational and labour market needs of the youths. At the tertiary level of education, Ubulom et al. (2006) carried a study to find out the counselling needs of the undergraduate students in Rivers State. In their study, they discovered that undergraduate students do not receive counselling services in all areas of their problems including their vocational and labour market needs.

From the foregoing therefore, it appears that theoretical research emphasis has always been placed on the need for guidance and counseling services to be provided at all levels of education and the counseling needs for the youths, but little or no empirical research study has been carried out on how young people perceive their vocational and labour market needs. This scenario seems to create a research-based knowledge gap, which this present study will empirically fill.

\section{Purpose of the Study}

The purpose of the study is to investigate the perception of school leavers about their vocational and labour market needs in Port Harcourt Metropolis. Specifically, the study attempted to identify the types of vocational and labour market needs available for the primary and secondary school leavers and to establish the type of perception primary school and secondary school levers hold about their vocational and labour market needs.

\section{Research Questions} study:
1. Which types of vocational needs exist for the primary school leavers?

2. What types of labour market needs exist for the primary school leavers?

3. Which types of vocational needs exist for the secondary school leavers?

4. What types of labour market needs exist for the secondary school leavers?

\section{Hypotheses}

The following hypotheses were formulated and tested at 0.05 level of significance:

1. There is no significant difference in the mean response scores of male and female primary school leavers on their perception regarding their vocational needs.

2. There is no significant difference in the mean response scores of male and female primary school leavers on their perception regarding their labour market needs.

3. There is no significant difference in the mean response scores of male and female secondary school leavers on their perception regarding their vocational needs.

4. There is no significant difference in the mean response scores of male and female secondary school leavers on their perception regarding their labour market needs.

\section{METHOD}

The study adopted research design and inquiry technique. This is because the study elicited responses from the respondents to establish difference existing between the responses about the variables investigated.

The target population for this study was made up of primary school pupils and secondary school students from secondary schools located in Port Harcourt Local Government Area of Rivers State. Stratified random procedure was adopted to select the sample size of one thousand subjects for the study. Five hundred (500) primary school pupils (that is, 250 male and 250 female) and five hundred (500) secondary school students (that is, 250 male and 250 female) were selected from ten (10) primary schools and ten (10) secondary schools, all located in Port Harcourt City Local Government Area of Rivers State and used as respondents for this study. The breakdown of the sample size is presented in table 1 .

The justification of using this sample size is 
Table 1: Sample size of primary school pupils and secondary school students

\begin{tabular}{|c|c|c|c|c|c|c|}
\hline $\begin{array}{l}\text { S. } \\
\text { No. }\end{array}$ & Primary School & Male & Female & Secondary School & Male & Female \\
\hline 1. & Baptist Day School & 25 & 25 & Govt. Comprehensive Secondary School Borikiri & 50 & NA \\
\hline 2. & Banham State School & 25 & 25 & Baptist High School, Port Harcourt & 50 & NA \\
\hline 3. & Holy Trinity & 25 & 25 & Enitona High School, Port Harcourt & 50 & NA \\
\hline 4. & St. John's Primary & 25 & 25 & Stella Maris College, Port Harcourt & 50 & NA \\
\hline 5. & Township School 1 & 25 & 25 & Govt. Secondary School, Borikiri & 50 & NA \\
\hline 6. & Township School 11 & 25 & 25 & Govt. Girls' Secondary School, Harbour Road & NA & 50 \\
\hline 7. & State School Churchill Road & 25 & 25 & Holy Rosary Secondary School, Port Harcourt & NA & 50 \\
\hline 8. & State School 1, Ibadan Street & 25 & 25 & Govt. Girls' Secondary School, Orominike & NA & 50 \\
\hline 9. & State School 11 Ibadan Street & 25 & 25 & Govt. Girls’ Secondary School, Rumueme & NA & 50 \\
\hline \multirow[t]{2}{*}{10.} & St. Cyprian's Primary & 25 & 25 & Govt. Girls' Secondary School, Rumuokwuta & NA & 50 \\
\hline & Total & 250 & 250 & Total & 250 & 250 \\
\hline
\end{tabular}

based on the fact that the pupils and students are future leaders of tomorrow and that they are undergoing educational training as a preparation for them to take up employment in the labour market, where they have to exhibit the vocational skills they have acquired through the primary or secondary school education. Hence, they are well informed about their vocational and labour market needs. The major instruments used in gathering data for this study are four rating scales namely; Perception of School Leavers' Vocational Needs Rating Scale (PSLVNRS) and Perception School Leavers' Labour Market Needs Rating Scale (PSLLMNRS).

Each of the instruments consists of five (5) items with options - Strongly Agree (SA), Agree (A), Disagree (D) and Strongly Disagree (SD). For the scoring of the instruments, $\mathrm{SA}=4, \mathrm{~A}=3$, $\mathrm{D}=2, \mathrm{SD}=1$. Some of the statements of the instruments are positively cued while others are negatively cued.

The instruments were subjected to both face and content validity. The instruments were given to two experts in Measurement and Evaluation and two Professionals in Guidance and Counselling all of the University of Calabar to validate. For the Reliability of the instrument, Test retest method was employed after which Pearson's Product Moment Co-relation Coefficient statistics was used for the analysis, and therefore arrived at the reliability coefficient scores of 0.86 , and 0.75 for PSLVNRS and PSLLMNRS respectively.

The instruments were administered to the respondents, one after the other. The instruments were personally administered by this researcher to the respondents during which about how the instruments will be completed were read and interpreted to them. This researcher ensured that the instruments were completely retrieved from the respondents after completion.
In order to analyse the data collected for this study, simple percentage and mean scores were computed and used to answer the research questions. Also, to test the hypotheses at 0.05 alpha level, t-test statistics was employed.

\section{RESULTS}

\section{Research Question 1}

Which types of vocational needs exist for the primary school leavers?

Table 2 shows that the mean response scores of the primary school leavers on their need to acquire technical knowledge to enable them fit into the present world of work is 3.35 , their need to be very good in science subjects is 3.55 , their need to be very good in arts subjects is 3.05 , their need to be computer literate is 3.41 and their need to be skilful in their areas of specialization is 2.72 , which are higher than the average mean score of 2.50. These indicate the types of vocational needs primary school leavers required. Table 2 also presents that the Grand Mean (GX) of the responses of primary school leavers about the types of vocational needs they required is 3.22 , indicating high level of perception of the primary school leavers about their vocational needs that can enable them function effectively in the present world of work.

\section{Research Question 2}

Which types of labour market needs exist for the primary school leavers?

Table 3 presents that the mean response scores of the primary school leavers on their need to have a job that can earn them good salaries is 3.79 , their need to select the work they will like to do is 3.53 , their need to work in any of the oil 
138

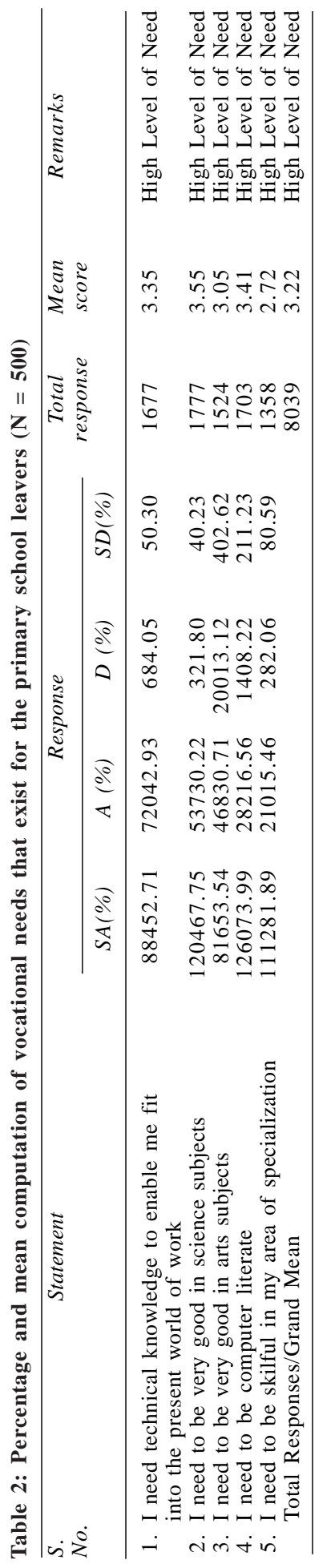

AMININIYE M. MANUEL AND PATRICK N. ASUQUO

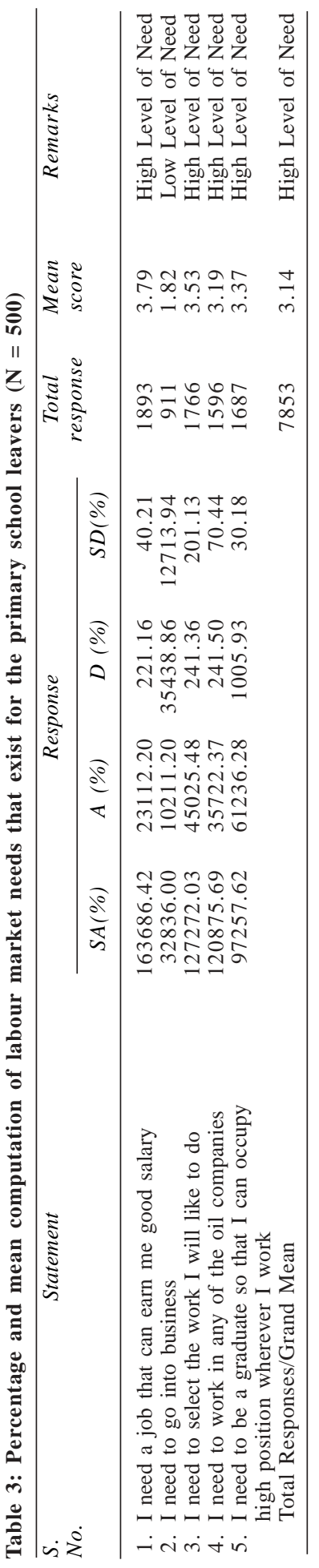


companies is 3.19 and their need to be a graduate so that they can occupy high positions wherever they work is 3.37, which are higher than the average mean score of 2.50. Again, the table shows that that the mean response scores of the primary school leavers on their need to go into businesses is 1.82 , which are lower than the average mean score of 2.50. These indicate the labour market needs primary school leavers required. Table 3 also presents that the Grand Mean (GX) of the responses of primary school leavers about their labour market needs is 3.14, indicating high level of perception of the primary school leavers about their labour market needs that can enable them fit into the present world of work.

\section{Research Question 3}

Which types of vocational needs exist for the secondary school leavers?

Table 4 shows that the mean response scores of the secondary school leavers on their need to acquire technical knowledge to enable them fit into the present world of work is 3.80 , their need to be very good in science subjects is 2.81 , their need to be very good in arts subjects is 3.16 , their need to be computer literate is 3.33 and their need to be skilful in their areas of specialization is 3.20 , which are higher than the average mean score of 2.50 . These indicate the types of vocational needs secondary school leavers required. Table 2 also presents that the Grand Mean (GX) of the responses of secondary school leavers about their vocational needs is 3.26, indicating high level of perception of the secondary school leavers about their vocational needs that can enable them function effectively in the present world of work.

\section{Research Question 4}

What types of labour market needs exist for the secondary school leavers?

Table 5 presents that the mean response scores of the secondary school leavers on their need to have a job that can earn them good salaries is 3.84 , their need to go into businesses is 3.36, their need to select the work they will like to do is 3.94 , their need to work in any of the oil companies is 3.64 and their need to be a graduate so that they can occupy high positions wherever they work is 3.46, which are higher than the average mean score of 2.50. These indicate the labour market needs secondary school leavers required.

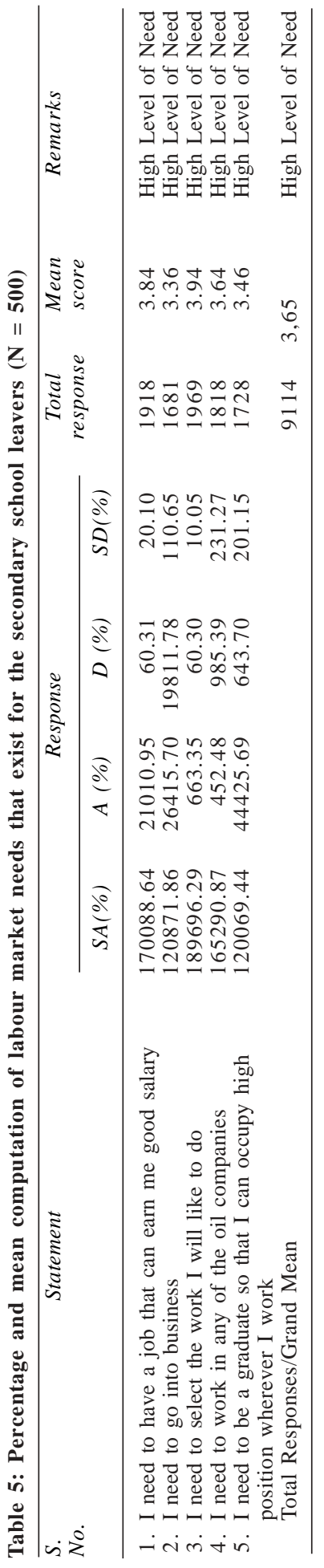


Table 3 also presents that the Grand Mean (GX) of the responses of secondary school leavers about their labour market needs is 3.65 , indicating high level of perception of the secondary school leavers about their labour market needs that can enable them fit into the present world of work.

\section{Hypothesis 1}

There is no significant difference in the mean response scores of male and female primary school leavers on their perception regarding their vocational needs.

The means and standard deviations of the responses of male and female primary leavers on their perception about their vocational needs are presented in the table 6 . With $\mathrm{N}=500, \mathrm{df}=498$ and $\mathrm{P}=0.05$, the calculated t-ratio between the responses concerning their perception was 0.3173 and the critical value of t-ratio was \pm 0.1980 . At this juncture therefore, the calculated t-ratio is not statistically significant at $\pm=0.05$ level of significance since it is less than the given critical value of t-ratio. The hypothesis $\left(\mathrm{HO}_{1}\right)$ is thus accepted and the conclusion is that there is no significant difference in the mean response scores of male and female primary school leavers on their perception regarding their vocational needs. This implies that no difference exists in the response scores of male and female primary school leavers on their perception regarding their vocational needs.

\section{Hypothesis 2}

There is no significant difference in the mean response scores of male and female primary school leavers on their perception regarding their labour market needs.
The means and standard deviations of the responses of male and female primary leavers on their perception about their labour market needs are presented in the table 7 . With $\mathrm{N}=500, \mathrm{df}=$ 498 and $\mathrm{P}=0.05$, the calculated t-ratio between the responses concerning their perception was 0.2983 and the critical value of t-ratio was \pm 0.1980 . At this juncture therefore, the calculated t-ratio is not statistically significant at $\pm=0.05$ level of significance since it is less than the given critical value of t-ratio. The hypothesis $\left(\mathrm{HO}_{2}\right)$ is thus accepted and the conclusion is that there is no significant difference in the mean response scores of male and female primary school leavers on their perception regarding their labour market needs. This implies that no difference exists in the response scores of male and female primary school leavers on their perception regarding their labour market needs.

\section{Hypothesis 3}

There is no significant difference in the mean response scores of male and female secondary school leavers on their perception regarding their vocational needs.

The means and standard deviations of the responses of male and female secondary school leavers on their perception about their vocational needs are presented in the table 8 . With $\mathrm{N}=500$, $\mathrm{df}=498$ and $\mathrm{P}=0.05$, the calculated $\mathrm{t}$-ratio between the responses concerning their perception was 0.4263 and the critical value of t-ratio was \pm 0.1980 . At this juncture therefore, the calculated t-ratio is not statistically significant at $\pm=0.05$ level of significance since it is less than the given critical value of t-ratio. The hypothesis $\left(\mathrm{HO}_{3}\right)$ is thus accepted and the conclusion is that there is no

Table 6: Difference in the mean response scores of male and female primary school leavers on their perception regarding their vocational needs

\begin{tabular}{lccccc}
\hline Variable & $N$ & Mean & Std Dev. & t-ratio Cal & t-ratio Crit \\
\hline Male & 250 & 2.8469 & 0.4254 & $0.3173+$ & \pm 0.1980 \\
Female & 250 & 2.7351 & 1.3623 & & \\
\hline $\mathrm{N}=500$ & & $\mathrm{df}=498$ & $\mathrm{P}>0.05 \quad+=$ Not Significant
\end{tabular}

Table 7: Difference in the mean response scores of male and female primary school leavers on their perception regarding their labour market needs

\begin{tabular}{lccccc}
\hline Variable & $N$ & Mean & Std Dev. & t-ratio Cal & t-ratio Crit \\
\hline Male & 250 & 2.6475 & 0.5212 & $0.2983+$ & \pm 0.1980 \\
Female & 250 & 2.5278 & 0.3521 & & P $>0.05$ \\
\hline $\mathrm{N}=500$ & $\mathrm{df}=498$ & &
\end{tabular}


significant difference in the mean response scores of male and female secondary school leavers on their perception regarding their vocational needs. This implies that no difference exists in the response scores of male and female secondary school leavers on their perception regarding their vocational needs.

\section{Hypothesis 4}

There is no significant difference in the mean response scores of male and female secondary school leavers on their perception regarding their labour market needs.

The means and standard deviations of the responses of male and female secondary school leavers on their perception about their labour market needs are presented in the table above With $\mathrm{N}=500, \mathrm{df}=498$ and $\mathrm{P}=0.05$, the calculated t-ratio between the responses concerning their perception was 0.4958 and the critical value of $t$ ratio was \pm 0.1980 . At this juncture therefore, the calculated t-ratio is not statistically significant at $\pm=0.05$ level of significance since it is less than the given critical value of t-ratio. The hypothesis $\left(\mathrm{HO}_{4}\right)$ is thus accepted and the conclusion is that there is no significant difference in the mean response scores of male and female secondary school leavers on their perception regarding their labour market needs. This implies that no difference exists in the response scores of male and female secondary school leavers on their perception regarding their labour market needs.

\section{DISCUSSION}

The results of this study indicate high levels of vocational and labour market needs among both primary and secondary school leavers. The results of this study also show no significant differences that exist in the mean response scores of male and female primary and secondary school leavers on their perception regarding their vocational needs. The results of this study support the finding of Eremie and Ubulom (2005) that discovered vocational components as one of the counselling areas of needs for primary school leavers.

An aspect of the results of this study provides that no significant differences that exist in the mean response scores of male and female primary and secondary school leavers on their perception regarding their labour market needs. The findings of this study support the views and findings of Olayinka (1993), Gesinde (1986) and Ubulom (1990), who earlier revealed that most young people prefer to choose medicine, engineering, law, architecture and pharmacy as the professions they intend to enter into after graduation from schools.

\section{CONCLUSIONS}

This study concludes that no difference exists in the response scores of male and female primary and secondary school leavers on their perception regarding their vocational and labour market needs. It is also necessary to conclude that the level of perception of the male and female primary and secondary school leavers about their vocational and labour market needs is high.

\section{RECOMMENDATIONS}

The following recommendations are made:

1. Primary school leavers should be provided with adequate careers counselling services to enable them further be aware of their vocation-al and labour market needs.

Table 8: Difference in the mean response scores of male and female secondary school leavers on their perception regarding their vocational needs

\begin{tabular}{lccccc}
\hline Variable & $N$ & Mean & Std Dev. & t-ratio Cal & t-ratio Crit \\
\hline Male & 250 & 2.6413 & 0.4232 & $0.4263+$ & \pm 0.1980 \\
Female & 250 & 2.8572 & 0.4216 & & \\
\hline $\mathrm{N}=500$ & & $\mathrm{df}=498$ & & $\mathrm{P}>0.05$ & + + Not Significant
\end{tabular}

Table 9: Difference in the mean response scores of male and female secondary school leavers on their perception regarding their labour market needs

\begin{tabular}{lccccc}
\hline Variable & $N$ & Mean & Std Dev. & t-ratio Cal & t-ratio Crit \\
\hline Male & 250 & 2.4157 & 0.9280 & $0.4958+$ & \pm 0.1980 \\
Female & 250 & 2.3577 & 1.2167 & & $\mathrm{P}>0.05$ \\
\hline $\mathrm{N}=500$ & $\mathrm{df}=498$ & & & + Not Significant
\end{tabular}


2. Career information services should be provided at the primary and secondary levels of education so as to acquaint the school leavers about the available labour markets.

3. Efforts should be intensified by government and school authorities to ensure that career units are established in all schools to aid students on their vocational and labour market needs.

\section{REFERENCES}

Anyaduba MO 1986. Address presented at the first anniversary of the Nigerian Association of Business Educators (NABE) at its conference held at the University of Benin on April, 1985. Business Education Journal, 2(1): $1-6$.

Eremie MD Ubulom WJ 2005. Counseling needs for primary school pupils in Port Harcourt metropolis. Journal of Technical and Science Education, 14(1\&2): 155 - 165 .

Gesinde SA 1986. Vocational theories as applied to the Nigerian cultural background. In: T Ipaye (Ed.):
Educational and Vocational Guidance: Concepts and Approaches. Ile Ife: University of Ife Press, pp. 230-239.

Obadofin B 1997. Introduction to Vocational Guidance and Counseling. Ibadan: Vinbet Publishers.

Olayinka MS 1993. Guidance and Counseling for Nigerian Schools. Lagos: Literamed Publications.

Olutola A 1986. Career choice. In: T Ipaye (Ed.): Educational and Vocational Guidance: Concepts and Approaches. Ile Ife: University of Ife Press, pp. 302-308.

Onyejiaku F 1987. Careers Guidance and Counseling Services In Schools. Calabar: Wusen Press.

Ubulom WJ 1999. Some factors influencing students' choice of career. Port Harcourt Journal of Psychology and Counseling, 5: 55-61.

Ubulom WJ 1990. Analysis of Attitudes towards Secretarial Career: A Survey of Quality Ranking Of Courses in Rivers State University of Science and Technology, Port Harcourt. B. Sc. Thesis, Unpublished. Rivers State University of Science and Technology, Port Harcourt.

Ubulom WJ, Eremie MD, Ubulom EW 2006. Guidance and counseling needs for undergraduate students in Rivers State. Journal of Technical and Science Education, 15(1\&2): 68 - 80 